\title{
19. Thinking with Cavell about (His) Death
}

\section{ERIC RITTER}

I am grateful to David LaRocca for inviting contributors to this special commemorative issue on the life and thought of Stanley Cavell. What follows is a brief philosophical reflection on what it means to think through the death of someone like Cavell, whose life and work continue to live on in so many respects and within so many people, as both this special issue and my experience in Stanley Cavell's study bear witness to. I would argue that it is difficult to think through Cavell's death adequately (that is, to get the right sort of concepts in play). The cause of this difficulty is a productive tension within the extraordinary ordinariness of the concept of death itself: between the fact of cessation of biological life and the various respects in which Cavell has not ceased to exist, especially within the hearts and minds of so many. I aim in this piece to think with Cavell-that is, using tools he has provided-about (his own) death, thus performing the very productive tension which is the subject of the essay. I interweave some anecdotes from the past year spent working with the Cavell family to inventory and organize Cavell's papers at the family's home in Brookline, Massachusetts.

\section{1.}

In August of 2019, a little more than a year after Stanley Cavell's death, I had the immense privilege of being present at the unveiling ceremony of his grave. For the occasion, a small group of Cavell's family had arrived at the family's home in Brookline, Massachusetts, to honor and celebrate Stanley Cavell's life. After the ceremony, and for the rest of the weekend, his presence lingered in the house. Our conversations kept returning to him. We even listened to a recording of Cavell masterfully playing jazz showtunes on the piano still standing in his living room. Yet despite those vari- 
ous presences, he-Stanley Cavell-was absent. His body had been buried next to his longtime friends and Harvard colleagues, John Rawls and Robert Nozick, across the Charles River in Mount Auburn Cemetery, Cambridge.

I was in Brookline that summer because Cathleen Cavell, Stanley's wife of fifty years and literary executor, designated me, after his death, to organize and catalogue the masses of books and documents and papers with which her husband had filled his study. The task was to design and implement an initial archival system to remain in place until the Cavell family decided to transfer the material to a library or archive suitable for scholarly research. With the guidance of Vanderbilt University librarians, I designed a replicable archival system, and read, studied, sorted, and inventoried more than two-dozen archival boxes full of print material, plus thousands of digital files. Perhaps most importantly, I rediscovered an unpublished manuscript called Here and There: Sites of Philosophy, now in the process of posthumous publication.

The very nature of the archival project suggests that Cavell's death will not mark the end of what we will learn from him. Despite his absence from his home, he was present in the books, notes, journals, and unfinished works, in his photographs and pens, in the synecdoche of his younger son's baseball on top of his many annotated editions of King Lear. It is this productive tension between Cavell's absence or non- existence (e.g., the burial) and his continued presences or existence (e.g., his study and unfinished work, his family and friends, future scholarship and other creative work indebted to him) that I aim to briefly explore here. How do we make sense of Cavell's death in light of such vibrant echoes of his life? The problem is that our everyday usage of the concept is not yet clear to us. Surprisingly, the everyday concept of death itself contains the keys to help make sense of such a tension, if we can follow out the heterogeneous and sometimes conflicting applications of it without seeking refuge in an essential or Platonist core.

2.

There are several places in his expansive body of work where Cavell explores the connection between the completion or termination of a sentence and the terminati- 
on of a variety of life-a "little death." There are also a few places in his work where Cavell registers the satisfaction of strong desire as a variety of, or as bearing a family resemblance to, a death. Taken together, we can take these family resemblances to provide the building blocks of a complex and unifying rule, or a conceptual web guiding many disparate applications, of the "concept" of death. In other words, to showcase something I have learned from Cavell, only after we have acquired a sense of the ordinary but extraordinary (taken together, one might say "uncanny") complexity and creativity within the everyday usage of the concept of death, can we begin to think philosophically about the meaning of Stanley Cavell's death.

Let us very briefly look at three quotations which help give shape to such a complex and creative concept. The first is from Cavell's preface to the updated edition of Must We Mean What We Say? (2002):

[...] I understand the presence of notable, surprising anticipations to suggest something more specific about the way, or space within which, I work, which I can put negatively as occurring within the knowledge that I never get things right, or let's rather say, see them through, the first time, causing my efforts perpetually to leave things so they can be, and ask to be, returned to. ${ }^{1}$

The second is from Conditions Handsome and Unhandsome (1990):

I mean to leave everything I will say, or have, I guess, ever said, as in a sense provisional, the sense, that is, to be gone on from. ${ }^{2}$

The third is from The Senses of Walden (1972, 1981):

Writing, at its best, will come to a finish in each mark of meaning, in each portion and sentence and word. 3

\footnotetext{
1. Cavell, "Preface to Updated Edition of Must We Mean What We Say?" in Must We Mean What We Say: A Book of Essays (Cambridge: Cambridge University Press, 2002), xvii.

2. Cavell, Conditions Handsome and Unhandsome: The Constitution of Emersonian Perfectionism (Chicago, IL: University of Chicago Press, 1990), 33.

3. Cavell, The Senses of Walden, An Expanded Edition (Chicago, IL: University of Chicago Press, 1992), 27.
} 
Permit me to put aside the obvious differences in theme and content for a moment. Taken together, these passages can be taken to mean that, far from the repeated termination of a thought or sentence, Cavell's philosophy never achieves an end or termination, never "sees a thought through" or "gets things right." And this reading is so much as possible because, within the reservoir of our ordinary language and ordinary practices, we "repeat" or "return" to something because it is not yet finished. If this way of reading him were correct, then Cavell might be said to have never finished any of his sentences, to have never left us to ourselves before.

However, this is not what I understand Cavell to be saying in these passages. To speak as an ordinary language philosopher-hence I am claiming and hoping for your agreement but I am also powerless to command it-we also "repeat" or "return" to something (a text, problem, question, or person) not only because we have not yet finished it, but also because we have not yet exhausted it. We-or what I hope is a "we" may come to have this relation to art objects and to people we love, for example, if we can find a way to "leave things so they can be, and ask to be, returned to." 4 It is in this latter sense of never exhausting a text or a thought, or of leaving things so that they ask to be returned to, that I read Cavell's report that he works "within the knowledge" that he "never get[s] things right," never "see[s] them through" the first time.5 Finishing or terminating a thought or sentence-a "mark"-need not mean exhausting the object of the thought. In fact, the completion of an act of understanding may serve to increase our interest in what we have understood. Paradoxically, then, Cavell suggests that in leaving a text or a thought so that it is asked to be returned to, we may actually achieve the "completion" or "finishing" of the thought we are aiming at. We can thus begin to envision a sense in which Cavell has passed away already, in the writing of each mark, in the completion of "each mark of meaning." 6

3.

To ask a more specific question, why does our thinking about a text, idea, film, or

4. Cavell, "Preface to Updated Edition of Must We Mean What We Say?," xvii (emphasis added).

5. One can detect a similar logic here in Cavell's description of the self of moral perfectionism as "a process of moving to, and from, nexts." Cavell, Conditions Handsome and Unhandsome, 12.

6. Cavell, The Senses of Walden, 27. 
other aesthetic object-to take the clearest case-not exhaust that object? Cavell's response goes hand in hand with a related (and broadly speaking post-Kantian) recognition: when we think and perceive we are synthesizing information through a particular and singular lens which is neither a distortion nor imposition, but a condition for meaningful thinking. We might describe this recurring heuristic in Cavell's philosophy as a variety of, say, modernist transcendental idealism. It requires recognizing the limitations of experience, history, or culture, not as limits but as conditions for thinking. I believe Cavell takes this insight equally from early Heidegger, later Wittgenstein, and from a self-consciousness of the consequences of his own complex identity as a first-generation immigrant, secular American Jew, father, teacher, writer, and academic philosopher.

Moreover, the idea that our specificity and singularity are revealed whether we like it or not-that we inevitably "stick our neck out"-in philosophical thinking is another of the most consistent, complex, and rich themes in Cavell's work. In his well-known working through of philosophical skepticism, for example, Cavell detects a desire for a picture or fantasy of knowledge in which our claims to know reveal nothing at all about us. As I understand him, Cavell holds that, for certain forms of assertions anyway, including even some kinds of empirical claims, it is impossible to "get to know" an aesthetic object or person or aspect of the natural world without exposing ourselves-the particularity and singularity of our experience, identity, history, and so forth-to being known. We understandably tend to avoid the responsibilities which come from being known in this way; Cavell's philosophy teaches us that avoiding such responsibilities has both epistemic and ethical consequences. Many of Cavell's most beautiful and dense sentences vibrate with an affirmation of their own contingent (but ineliminable) conditions of singularity and particularity.

Finally, in terms of the form of these three passages, I take Cavell to be giving voice to something like philosophical reminders, in later Wittgenstein's sense. Such reminders are actively aimed at intervening in our lives by assisting us in an acknowledgment of a fantasy (of limitlessness, totality, or completion). The purpose of a reminder is importantly different from the purpose of a definition or rule, for example, for what counts as "seeing a thought through" or "coming to a finish in each mark." The aim of a philosophical reminder is to do something (with the words which 
comprise the reminder): to successfully complete the speech act of reminding, and hence to counteract a particular habit or act of mental activity. Perhaps parts of Cavell's philosophy speak (only?) to those individuals who have come to self-consciousness about repeated temptations toward transcending or denying their rootedness in a particular embodied, temporal, and historical set of experiences.

\section{4.}

To bring these thoughts back to the subject of death, we can detect, in the philosophical reminders Cavell provides us of our own particularity and singularity, several family resemblances within the concept of death. There is first of all the death or termination of a fantasy of limitlessness, totality, or completion. Such a reminder to recognize one's particularity goes hand-in-hand with the recognition that the object of thought has not been exhausted, because it is a reminder of the "lens" through which one's experience of objects is refracted. Even if the counteraction of this fantasy allows for thinking, it is still difficult, because it requires giving something up.

But there is also, second of all, in these connections between death and thinking, a kind of indirect reminder that we live in time, that our thinking is conditioned by the passage of time, and hence that we will one day die. This Heideggerian echo can be read as pervading Cavell's philosophical reminders about our singularity and particularity in the following way. If there is something disappointing about the fact that our thinking cannot be "complete" in the sense of exhausting everything there is to say about a given text, person, or piece of art, then perhaps we harbor a disappointment about our "fatedness" (to use a Cavellian term) to living in time. Relatedly, perhaps there is something disappointing about the reality of our fatedness to continual growth and education in time. These are key Cavellian themes: that we harbor deep desires to deny not just significant but constitutive facts of our finite, earthly, and temporal condition. Again these limitations will show up in particular cases as barriers rather than conditions for thinking, and in each case we will need to find our way (back) to the ordinariness of living in time-which is also a living toward death. 
In this sense Cavell's philosophy might be said to echo Plato's metaphilosophical description of philosophy as a "preparation for death." Each time we return to the ordinary (a place we have never been), we are also returning to the reality of death by resituating ourselves in time. It does not seem like an exaggeration to say that thinking in Cavell's philosophy is itself a "little death"-revealing the limits of our own experience and reminding us that we are beings who live in time.

In some respects Cavell's philosophy can be read as a theatre of the encounter between constitutive facts of finitude, such as our fatedness to living in time, and their denial. This region of Cavell's thinking might be described as a set of insights gleaned from encounters with the fantasies which would deny them. Cavell's philosophy is thus dialectical in this respect. However, this way of thinking is diminished when it is treated as a fact about something Cavell said or believed, rather than as a heuristic for one’s own grappling with philosophical questions.

\section{5.}

Finally, if we take Cavell at his word that he meant "to leave everything I will say, or have, I guess, ever said, as in a sense provisional [...] that is, to be gone on from,"7 then he might be described as having already passed away (in each new instant of "completing" a sentence-and thus, as having passed away as early as his earliest writings). With the completion of each sentence, with the finishing of each "mark of meaning," 8 and with the satisfaction of the desire therein, there are countless little deaths strewn across his work. But aside from the interesting question of how to understand further these interplays or family resemblances, what does the fact of these family resemblances suggest about the meaning of Cavell's "literal" death? In other words, is Cavell's actual death-to which I bore witness at the occasion of the unveiling ceremony-the core or center of the concept of death, making these various "little deaths" in his written work mere ornaments or figurative extensions of that core?

7. Cavell, Conditions Handsome and Unhandsome, 33.

8. Cavell, The Senses of Walden, 27. 
Cavell's answer, I believe, is that we should not think about concepts as having a literal or essential "core" with merely figurative or secondary or ornamental extensions protruding from that core. 9 Concepts such as death have an ordinary yet extraordinary complexity and texture which will be missed if we posit an essential or literal core. There is an uncanny sense in which we both possess an understanding or a "concept" of death and yet-since that concept cannot be reduced to a core rule or essential decision procedure-we do not possess an exhaustive or complete understanding of it. We both possess the concept of death and, in our efforts to understand the entirety of what we possess, it falls away from our grasp. Yet our wish to grasp the concept's essential core reveals our desire to exhaust the object of our thought, a desire which is strangely self-defeating, since it ends up making it impossible for us "finish" or "complete" it. What I have learned from Cavell is that we arguably require an awareness of such an ungraspable, expansive, and elusive conceptual web in order to understand our own experience-that is, we arguably require philosophy in order to understand our own experience. If we want to capture, let alone make sense of, the fact that Cavell continues to mean so many different things to so many different people, then the (extra)ordinary ordinariness of the concept of death is required. It is a concept which, if we can hear it, both registers the cessation of life and registers the continued "aliveness" of a thinker like Cavell.

Has Stanley Cavell died? Undoubtedly. His body is buried in Mt. Auburn cemetery, in Cambridge. Yet he continues to teach me how to think. On Cavell's account, it is the surprising structure of concepts themselves that encourage us, as we follow them, to retreat from the habitual in order to think: in which each instance of the concept is connected to every other, some closer and some farther from familiar usage, yet none of them absolutely core or essential. If Cavell has taught us how to think, then we are thinking with Cavell about (his own) death, thus performing the very tension between life and its afterlives which is the subject of the essay. As we do so, we find that in thinking philosophically, we are also coming to know the limits of our own experience and are thus reminded that we are beings who live in time. We tin Gustaffson, "Familiar Words in Unfamiliar Surroundings: Davidson's Malapropisms, Cavell's Projections," International Journal of Philosophical Studies 19, no. 5 (2011): 643-68. 
also find that Cavell is still "alive" in everything he has left behind, from the treasure of his study to his friends and family, and not least in the tools to affirm the creativity, complexity and partiality of "our" human grasp of the very concept of death itself.10 